\title{
Digestibility and fecal characteristics of dogs fed with Bacillus subtilis in diet
}

\author{
Digestibilidade e características das fezes de cães suplementados com Bacillus subtilis na dieta
}

\author{
Ananda Portella Félix ${ }^{\mathrm{I}}$ Marina Volanski Teixeira Netto ${ }^{\mathrm{II}}$ Fabiane Yukiko Murakami ${ }^{\mathrm{I}}$ \\ Cleusa Bernardete Marcon de Brito ${ }^{\mathrm{I}}$ Simone Gisele de Oliveira ${ }^{\mathrm{III}}$ Alex Maiorka ${ }^{\text {III* }}$
}

\begin{abstract}
Considering the benefice demonstrated by the modulating action of probiotics on the host intestinal microbiota, this study aimed to evaluate diet digestibility and fecal characteristics of dogs fed with diets supplemented with Bacillus subtilis (C-3102). Twelve young Beagle dogs were distributed in a completely randomized experimental design consisting of two treatments: diet with no addition or with the addition of $0.01 \%$ Bacillus subtilis (C-3102). Dogs passed through 25 days of adaptation to the diets, and five days of total feces collection. The following fecal characteristics were evaluated: $\mathrm{pH}$, fecal score (1 - watery feces; 5: dry and hard feces), and ammonia content. Diet mean digestibility was compared by the Tukey test, and fecal characteristics by the Tukey-Kramer test. Diet digestibility was not different between treatments, but dogs supplemented with the tested probiotic presented dryer feces $(39.1 \%$ vs. $36.5 \%$ dry matter), higher fecal score (3.4 vs. 3.0) and lower fecal ammonia content $(0.45 \%$ vs. $0.56 \%)$, than dogs fed with the control diet. The dietary supplementation with Bacillus subtilis (C-3102) improves fecal texture and odor in dogs.
\end{abstract}

Key words: fecal texture, intestinal health, intestinal microbiota, probiotics.

\section{RESUMO}

Em virtude da capacidade moduladora dos probióticos sobre a microbiota intestinal a favor da saúde do hospedeiro, objetivou-se, com este estudo, avaliar a digestibilidade e as características das fezes de cães suplementados com Bacillus subtilis (C-3102) na dieta. Foram utilizados 12 cães adultos da raça Beagle, os quais foram distribuídos inteiramente ao acaso, em dois tratamentos: dieta controle e dieta com adição de 0,01\% de Bacillus subtilis $(C$ 3102). Os animais passaram por 25 dias de adaptação às dietas e por cinco dias para colheita total de fezes. As características das fezes foram avaliadas por meio da matéria seca, do escore (1: fezes moles, malformadas a 5: fezes secas e duras), do pH, da amônia e da produção de fezes. Não houve diferença na digestibilidade; entretanto, os cães suplementados com probiótico apresentaram fezes mais secas $(39,1 \%$ vs. $36,5 \%$ de matéria seca), com maior escore $(3,4 \mathrm{vs} .3,0) e$ menor teor de amônia (0,45\% vs. 0,56\%), quando comparados com os alimentados com a dieta controle. A suplementação com Bacillus subtilis (C-3102) melhora a consistência e diminui $o$ odor das fezes dos cães.

Palavras-chave: consistência das fezes, microbiota intestinal, probiótico, saúde intestinal.

\section{INTRODUCTION}

The excessive growth of some microorganisms in the intestine may cause several intestinal disorders. One of the most frequently used therapeutic measures to treat diseases caused by bacteria is antibiotics. Despite of being efficient in most cases, this method may promote the emergence of resistant microbial strains, and causes the elimination of most of the beneficial intestinal microbiota (SUNVOLD \& REINHART, 1998), which is a key for intestinal physiological function.

'Programa de Pós-graduação em Ciências Veterinárias, Universidade Federal do Paraná (UFPR), Curitiba, PR, Brasil.

${ }^{\text {II } C u r s o ~ d e ~ Z o o t e c n i a, ~ U F P R, ~ C u r i t i b a, ~ P R, ~ B r a s i l . ~}$

"I'Departamento de Zootecnia, UFPR. Rua dos Funcionários, 1540, Cabral, 80035-050, Curitiba, PR, Brasil. E-mail: amaiorka@ufpr.br. *Autor para correspondência. 
The use of probiotics is a prophylactic alternative to the use of antibiotics. Probiotics may be defined as living microorganism colonies that, when supplemented in diet, benefit the host by modulating the intestinal microbiota in favor of non-pathogenic microorganisms. The most common genera used as probiotics are those that produce lactate, such as Lactobacillus spp. and Bifidobacterium spp. Despite of being less frequently used as probiotics in dogs, bacteria of the genus Bacillus have the advantage of sporulating, and thereby are more resistant to environmental stress and to acid pH(BIOURGE et al., 1998).

Probiotics may inhibit the development of pathogenic bacteria by competing for nutrients and for binding sites in the intestinal epithelium, stimulating the host's immune system, producing antimicrobial substances, and acidifying the intestines as a result of acid production, particularly of lactic acid. Moreover, according to SALMINEN et al. (1998), GHADBAN (2002), and SWANSON et al. (2002), probiotics synthesize vitamins, enzymes, and short-chain fatty acids (SCFA), which effects may benefit the host. These effects include reducing lactose intolerance, immunomodulation, shortening diarrhea episodes, and lowering the formation of putrefactive compounds, such as ammonia, which are responsible for foul fecal odor and colon carcinogenesis. In addition, they may promote nutrient digestion and water absorption.

Considering the potential beneficial effects of probiotics on dog intestinal health and fecal characteristics, the present study aimed to evaluate diet digestibility and fecal characteristics of dogs fed with diets supplemented with probiotic (Bacillus subtilis, C-3102).

\section{MATERIAL AND METHODS}

Twelve 7- to 8-month-old healthy male and female Beagle dogs, previously vaccinated and dewormed, with an average body weight of $9.0 \pm 1.2 \mathrm{~kg}$, were used. The dogs were raised and housed during the experiment at the kennel of the Laboratory of Canine Nutrition Studies (Laboratório de Estudos de Nutrição Canina - LENUCAN), located at the Agrarian Sciences campus of the Federal University of Paraná (UFPR).

Two diets were evaluated: a basal diet (control), and a diet supplemented with $0.01 \%$ of the probiotic Bacillus subtilis $\left(\mathrm{C}-3102 ; 1 \times 10^{10} \mathrm{CFU} \mathrm{g}{ }^{-1}\right)$ (Table 1). This probiotic was added to $300 \mathrm{~mL}$ soybean oil and mixed to a commercial dry extruded puppy feed in a Y mixer for $15 \mathrm{~min}$. The same commercial diet was used as the control diet, to which $300 \mathrm{~mL}$ soybean oil were added so that both diets contained equal energy levels.
Table 1 - Chemical composition determined in the experimental diets.

\begin{tabular}{llc}
\hline (\% dry matter) & Control & Probiotic $^{{ }^{1}}$ \\
\hline Crude protein (CP) & 28.7 & 28.3 \\
Acid ether extract (AEE) & 11.3 & 11.2 \\
Crude fiber (CF) & 1.5 & 1.5 \\
Mineral matter (MM) & 9.9 & 9.7 \\
$\begin{array}{ll}\text { Non-nitrogen extract (NNE) } \\
\text { Metabolizable energy }\end{array}$ & 48.4 & 49.3 \\
$\left(\mathrm{kcal} \mathrm{g}^{-1}\right)^{* 3}$ & 3.7 & 3.7 \\
\hline
\end{tabular}

${ }^{* 1} 0.01 \%$ Bacillus subtilis (C-3102), at a concentration of $1 \mathrm{x}$ $10^{10} \mathrm{CFU} \mathrm{g}^{-1}$.

${ }^{* 2}$ Estimated as: NNE $(\%)=100-(\mathrm{MM} \%+\mathrm{CP} \%+\mathrm{AEE} \%+$ CF\%).

${ }^{* 3}$ Estimated as: ME $\left(\mathrm{kcal} \mathrm{g}^{-1}\right)=[(3.5 \mathrm{x} \mathrm{CP} \%+8.5 \times$ AEE $\%+3.5$ $\mathrm{x}$ NNE\%)] $/ 100$.

Bacillus subtilis (C-3102) concentration was analyzed in both diets using a pool of samples collected from several points of the feed bag. The pool was ground to $1 \mathrm{~mm}$, after which $5 \mathrm{~g}$ of the pool were incubated in Trypticase Soy Broth (BBL) ${ }^{\circledR}$ with $2 \%$ agar for subsequent counting of Bacillus subtilis colony forming units $\mathrm{g}^{-1}$ of feed.

The treatment diets were offered to the dogs for an adaptation period of 25 days, followed by five days of total fecal collection. Dogs were housed in masonry pens with solarium for the first 20 days, and then placed in metabolic cages $(0.7 \mathrm{~m}$ high $\mathrm{x} 0.6 \mathrm{~m}$ long $\mathrm{x}$ $0.5 \mathrm{~m}$ wide), where they remained for ten days (five days of adaptation to the cages, and five days of total feces collection), as recommended by the AAFCO (2004).

Feeds were offered once daily, at 07:30 am, in amount sufficient to supply the dogs' metabolizable energy requirements (MER) according to the formula: MER $=130 \mathrm{x}$ body weight $\mathrm{t}^{0.75}$, proposed by the NRC (2006). Water was available ad libitum. Feces were collected and weighed immediately after excretion, and submitted to the laboratory for analyses.

The following fecal characteristics were evaluated: fecal score, dry matter, ammonia, $\mathrm{pH}$, and fecal output. Fecal score was evaluated always by the same researcher in a 1 to 5 scale as:: 1 = very soft feces; $2=$ soft, unshaped feces that took the shape of the collection vessel; $3=$ soft, shaped and moist feces that left a mark on the floor; $4=$ shaped and solid feces that did not adhere to the floor; $5=$ shaped, dry, and hard feces (SÁ-FORTES, 2005).

Fresh feces from each individual animal were separately homogenized, from which a sample was taken to determine ammonia content according to the AOAC (1995). Fecal $\mathrm{pH}$ in fresh feces was measured in a 2-g sample, which was diluted in $20 \mathrm{~mL}$ distilled water 
and measured using a digital $\mathrm{pHmeter}$. In feces dried for 48 hours at $55^{\circ} \mathrm{C}, \mathrm{pH}$ was measured by diluting $2 \mathrm{~g}$ dry feces in $20 \mathrm{~mL}$ distilled water and using a digital pHmeter, according to WALTER et al. (2005). The remaining sample was dried in a forced-ventilation oven at $55^{\circ} \mathrm{C}$ until constant weight.

Diet samples and fecal samples dried at $55^{\circ} \mathrm{C}$ were analyzed to determine the contents of: dry matter at $105^{\circ} \mathrm{C}(\mathrm{DM})$, crude protein $(\mathrm{CP})$, crude fiber (CF), mineral matter $(\mathrm{MM})$ and ether extract in acid hydrolysis (AEE), according to the methods described by the AOAC (1995). The fraction corresponding to non-nitrogen extract (NNE) was calculated according to the formula: $\mathrm{NNE} \%=100-(\% \mathrm{M}+\% \mathrm{CP}+\% \mathrm{CF}+\% \mathrm{AEE}+\% \mathrm{MM})$, where $\mathrm{M}$ is the moisture content of the sample (100-\%DM). Dietary and fecal gross energy (GE) was determined in a calorimetric bomb. Metabolizable energy (ME) was estimated according to $\mathrm{AAFCO}$ (2004) as:

$\mathrm{ME}\left(\mathrm{kcal} \mathrm{g}^{-1}\right)=\left\{\mathrm{kcal} \mathrm{g}^{-1} \mathrm{GE}\right.$ intake - $\mathrm{kcal} \mathrm{g}^{-1}$ GE excreted in the feces - [(g CP intake - $\mathrm{g}$ CP excreted in the feces) $\left.\left.x 1.25 \mathrm{kcal} \mathrm{g}^{-1}\right]\right\} / \mathrm{g}$ feed intake

Based on the laboratory results, the apparent digestibility coefficients (ADC) of the experimental diets were determined using the equation proposed by MATTERSON et al. (1965):

$\mathrm{ADC} \%=[$ (nutrient intake - nutrient excretion)/ nutrient intake] x 100

A completely randomized experimental design in a split-plot in time was applied (main plot: treatments, subplot: days), with five days of data collection and six dogs per treatment, totaling 30 observations per treatment for the evaluation of fecal characteristics. A completely randomized experimental design with two treatments and six replicates per treatment was applied to analyzed diet digestibility, which was determined in the pool of feces samples collected during five days of each individual dog.
Data were previously analyzed to verify the normality residue and variance homogeneity, and logtransformed when necessary. ADC data were submitted to analysis of variance using the GLM procedures of the SAS (1996) statistical package. Means were compared by the test of Tukey at 5\% probability level. Fecal characteristic data were analyzed using the Mixed procedure of SAS (1999) statistical package, and means were compared by the test of Tukey-Kramer at $5 \%$ probability level.

\section{RESULTS AND DISCUSSION}

There were no ADC and metabolizable energy differences between the control diet and the diet supplemented with the probiotic $(\mathrm{P}>0.05)$ (Table 2$)$. In a study using probiotics, BIOURGE et al. (1998) also did not find any differences in ADC of dry matter, crude protein, ether extract, and metabolizable energy in dogs fed with a diet containing $7.5 \times 10^{6} \mathrm{CFU}$ Bacillus (C-5832) or a control diet. However, other studies with dogs demonstrated that the dietary supplementation with probiotics containing bacteria of the genus Lactobacillus promoted higher dry matter ADC (SWANSON et al., 2002) and higher energy metabolizability coefficient (FELICIANO, 2008). Better energy utilization was also reported by UTIYAMA (2004) in weaned piglets fed diets supplemented with bacteria of the genus Bacillus.

The intestinal microbiota plays an important role in the normal physiological intestinal function, preventing intestinal colonization by pathogenic microorganisms. In addition, it fermented dietary fiber, producing SCFA, particularly acetate, propionate, and butyrate, which are the main energy source of colonocytes (SIMPSON, 1998). According to the NRC (2006), the presence of SCFA stimulates the secretion

Table 2 - Apparent digestibility coefficients (ADC) and metabolizable energy of the control diet and the diet with probiotics in dogs (means \pm standard error).

\begin{tabular}{lccc}
\hline Variables & Control & Probiotic ${ }^{{ }^{1}}$ & CV (\%) \\
\hline Dry matter & $82.1 \pm 0.44$ & $82.4 \pm 0.70$ & 1.68 \\
Organic matter & $86.3 \pm 0.29$ & $86.6 \pm 0.54$ & 1.20 \\
Crude protein & $85.3 \pm 0.19$ & $85.1 \pm 0.74$ & 1.49 \\
Acid etther extract & $91.7 \pm 0.31$ & $91.0 \pm 0.37$ & 0.96 \\
Non-nitrogen extract & $88.3 \pm 0.29$ & $89.0 \pm 0.45$ & 1.09 \\
Metabolizable energy (kcal.g-1) & $3.4 \pm 0.02$ & $3.4 \pm 0.02$ & 1.28 \\
\hline
\end{tabular}

${ }^{* 1} 0.01 \%$ Bacillus subtilis (C-3102) at a concentration of $1 \times 10^{10} \mathrm{CFU} \mathrm{g}{ }^{-1}$.

$\mathrm{CV}$ : coefficient of variation.

Ciência Rural, v.40, n.10, out, 2010. 
of glucagon like-peptide 2, which stimulates cell differentiation and proliferation, as well as the expression of genes related to nutrient transport in the ileum, and therefore, may improve animal's digestive function. Moreover, growth of mucosa also improves its barrier function, reducing microorganism translocation. In addition to digestibility, fecal characteristics should also be considered when evaluating dog food quality. Dog owners look for foods that produce lower fecal output, and drier feces with less odor. In addition, feces appearance may be a reflex of the dog's intestinal health.

Fecal characteristics results are shown in table 3. Although fecal score was considered optimal (3-4) in both treatments, the dogs supplemented with Bacillus subtilis presented higher fecal score, higher dry matter content, and lower ammonia concentration as compared to those fed with the control $\operatorname{diet}(\mathrm{P}<0.05)$. Fecal $\mathrm{pH}$ and output were not different between treatments $(\mathrm{P}>0.05)$.

In the study carried out by SWANSON et al. (2002) no differences in fecal $\mathrm{pH}$, dry matter, score, and ammonia concentration were found in dogs fed twice a day with $1 \times 10^{9} \mathrm{CFU}$ Lactobacillus acidophilus in a gelatin capsule. However, the authors observed softer feces and lower fecal $\mathrm{pH}$ in dogs fed with Lactobacillus combined with fructoligosaccharides. On the other hand, FELICIANO (2008) reported fecal $\mathrm{pH}$ reduction in dogs fed with Lactobacillus in the diet.

The fact that no fecal $\mathrm{pH}$ differences were detected in the present study is due to the limited capacity of lactic acid production of the species Bacillus subtilis, as compared to bacteria of the genus Lactobacillus. In addition, as SCFA are readily absorbed by the colonocytes, their concentration in the feces is very low, and therefore it is not possible to obtain significant fecal $\mathrm{pH}$ reduction due to the higher production of SCFA by $\boldsymbol{B}$. subtilis in the intestine. The absorption of the SCFA produced by intestinal microorganisms stimulates water and electrolyte absorption, which is directly linked to intestinal osmoregulation. SCFA production increases sodium absorption rate, which accounts for most of the water absorbed in the intestinal lumen (HERSCHEL et al., 1981), explaining the excretion of drier feces.

Although the concentration of fecal microorganisms was not evaluated in the present study, it is possible that the lower fecal ammonia content observed was due to a limitation in the replication of pathogenic microorganisms in the gut of dogs fed with probiotics. Several pathogenic bacteria, including Clostridium perfringens, metabolize nitrogen compound, generating putrefactive catabolites, such as biogenic amines, and phenols that account for the foul odor of feces. In addition, many of these catabolites may negatively influence intestinal health, as high ammonia concentrations seem to disturb cell turnover, contributing to colon carcinogenesis (LIN \& VISEK, 1991).

The use of different genera, strains, and concentrations account for the wide differences reported in literature as effect of probiotic supplementation in diets. Moreover, the different compositions of the experimental diets, particularly the fermentable oligosaccharide concentrations, also influence the results, making difficult to make conclusions about which probiotics and concentrations are more effective when supplemented in commercial diets. Another important factor mentioned in the survey carried out by WEESE (2002) on commercial probiotics used in livestock feeds and pet foods was that the concentration of microorganisms was below the level guaranteed in the label of most commercial probiotic products.

Table 3 - Fecal characteristics of dogs fed with a control diet and a diet with probiotic (mean \pm standard error).

\begin{tabular}{lllc}
\hline Variables & Control & Probiotic $^{{ }^{* 1}}$ & CV $(\%)$ \\
\hline Fecal score & & 18.1 \\
Dry matter $(\%)$ & $3.0 \pm 0.11^{\mathrm{b}}$ & $3.4 \pm 0.09^{\mathrm{a}}$ & 9.2 \\
pH in fresh feces & $36.5 \pm 0.54^{\mathrm{a}}$ & $39.1 \pm 0.64^{\mathrm{b}}$ & 3.5 \\
pH in dry feces & $6.7 \pm 0.08$ & $6.6 \pm 0.04$ & 5.4 \\
Ammonia $(\%)$ & $6.0 \pm 0.02$ & $6.0 \pm 0.05$ & 18.5 \\
gfecalDM kgBW $^{-1}$ day $^{-1 * 3}$ & $0.56 \pm 0.02^{\mathrm{a}}$ & $0.45 \pm 0.01^{\mathrm{b}}$ & 33.2 \\
\hline
\end{tabular}

\footnotetext{
${ }^{a, b, c}$ Means in the same row followed by different superscript are different bu the test of Tukey-Kramer $(\mathrm{P}<0.05)$.

$\mathrm{CV}$ : coefficient of variation.

${ }^{* 1} 0.01 \%$ Bacillus subtilis (C-3102) at a concentration of $1 \times 10^{10} \mathrm{CFU} \mathrm{g}^{-1}$.

${ }^{*}$ Fecal score: 1: unshaped and very soft stools to 5: shaped, dry, and hard stools.

${ }^{* 3}$ Dry matter fecal output (g) per day.dog body weight $(\mathrm{kg})^{-1}$.
} 


\section{CONCLUSION}

The supplementation of $0.01 \%$ Bacillus subtilis in the food improves fecal characteristics and intestinal health of dogs by reducing fecal ammonia concentration and producing drier feces.

\section{REFERENCES}

AAFCO (Association of American Feed Control Officials). Oxford, 2004. 276p. (Official Publication).

AOAC (Association of the Official Analytical Chemists). Official and tentative methods of analysis. 16.ed. Arlington, 1995. 2000p.

BIOURGE, V. et al. The use of probiotics in diets of dogs. Journal of Nutrition, v.128, p.2730S-2732S, 1998. Available from: <http://jn.nutrition.org/cgi/reprint/128/12/2730S>. Accessed: Jun. 30, 2008.

FELICIANO, M.A.R. Suplementação de probiótico para cães da raça beagles recebendo alimentos comerciais. 2008. 110f. Dissertação (Mestrado em Zootecnia) Universidade Federal de Lavras, Lavras, MG

GHADBAN, G.S. Probiotics in broiler production - a review. Archives Geflugelk, v.66, n.2, p.49-58, 2002. Available from: <http://www.docin.com/p-6789324.html>. Accessed: Jun. $30,2008$.

HERSCHEL, D.A. et al. Absorption of volatile fatty acid, Na, and $\mathrm{H} 2 \mathrm{O}$ by the colon of the dog. American Journal of Veterinary Research, n.42, p.1118-1124, 1981.

LIN, H.C.; VISEK, W.J. Large intestinal $\mathrm{pH}$ and ammonia in rats: dietary fat and protein interactions. Journal of Nutrition. v.121, p.832-843, 1991. Available from: <http:// jn.nutrition.org/cgi/reprint/121/6/832.pdf>. Accessed: Jan. 22, 2008 .

NACIONAL RESEARCH COUNCIL. Nutrient requirements of dogs. Washington: National Academy, 1985. $79 \mathrm{p}$
SÁ-FORTES, C.M.L. Valor nutricional de ingredientes energéticos e protéicos para cães. 2005. 82f. Tese (Doutorado em Zootecnia) - Universidade Estadual Paulista, Jaboticabal, SP.

SALMINEN, S. et al. Demonstration of safety of probiotics - a review. International Journal of Food Microbiology, v.44, p.93-106, 1998. Available from: <http://www.ncbi.nlm.nih.gov/ pubmed/9849787>. Accessed: Feb. 12, 2008.

SAS Statistical Analysis System: users guide. Cary, NC, 1996. $584 \mathrm{p}$.

SIMPSON, J.W. Diet and large intestinal disease in dogs and cats. Journal of Nutrition. v.128, p.2717-2722, 1998. Available from: <http://jn.nutrition.org/cgi/content/full/128/12/ 2717S>. Accessed: Feb. 12, 2008.

SUNVOLD, G.D.; REINHART, G.A. Use of novel fibers in canine gastrointestinal disease. In: ANNUAL VETERINARY MEDICAL FORUM, 16., 1998, California. Anais... California: American College of Veterinary Internal Medicine, 1998. p.97101.

SWANSON, K. et al. Fructooligosaccharides and Lactobacillus acidophilus modify gut microbial populations, total tract nutrient digestibilities and fecal protein catabolite concentrations in healthy Adult dogs. Journal of Nutrition, n.132, p.37213731, 2002. Available from: <http://jn.nutrition.org/cgi/ content/full/132/12/3721>. Accessed: Jun. 25, 2008.

UTIYAMA, C.E. Efeitos de antimicrobianos, prebióticos, probióticos e extratos vegetais sobre a microbiota intestinal, a freqüência de diarréia e o desempenho de leitões recémdesmamados. Revista Brasileira de Zootecnia, v.35, p.23592367,2004

WALTER, M. et al. Biological response of rats to resistant starch. Revista do Instituto Adolfo Lutz, v.64, n.2, p.252257, 2005.

WEESE, J.S. Evaluation of deficiencies in labeling of commercial probiotics. Canadian Veterinary Journal, v.44, p.982-983, 2002. Available from: <http://www.ncbi.nlm.nih.gov/pmc/ articles/PMC340366/>. Accessed: Jun. 25, 2008. 